\title{
Thermoregulatory responses of sindhi and guzerat heifers under shade in a tropical environment
}

\section{Respostas termorregulatórias de novilhas sindi e guzerá sob condições de sombra em um ambiente tropical}

\author{
Vinícius de França Carvalho Fonsêca ${ }^{1 *}$; Ebson Pereira Cândido²; \\ Severino Gonzaga Neto ${ }^{3}$; Edilson Paes Saraiva3; Dermeval de Araújo Furtado ${ }^{4}$; \\ Jean Francisco Pereira Gama ${ }^{5}$; George Vieira do Nascimento ${ }^{5}$; \\ Carla Aparecida Soares Saraiva ${ }^{3}$; Gabriel Henrique Oliveira Almeida ${ }^{1}$
}

\begin{abstract}
This study characterized the thermal environment and assessed the physiological aspects of acclimatization of Sindhi and Guzerat heifers in a tropical environment (Brazil) under shade. Eight Sindhi and eight Guzerat purebred heifers (Bos indicus) had their physiological traits measured twice a day (9:00 a.m. and 2:00 p.m.). Environmental data during the experimental period were collected at two-hour intervals between 5:00 a.m. and 5:00 p.m. The temperature-humidity (THI) and the black globe temperature-humidity (BGHI) indices were calculated, and surface temperature $\left(\mathrm{S}_{\mathrm{t}}\right)$, respiratory rate $\left(R_{r}\right)$, and rectal temperature $\left(R_{t}\right)$ were collected, being used to estimate heat loss by cutaneous $\left(E_{c}\right)$ and respiratory $\left(E_{r}\right)$ evaporation. In the warmer parts of the day (1:00 and 3:00 p.m.), the THI and BGHI reached values of 80.26 and 81.25 , respectively. There was no significant difference in rectal temperatures between the breeds, but higher values were observed in the afternoon. Heat transfer by cutaneous evaporation reached $118.71 \pm 12.91 \mathrm{~W} \cdot \mathrm{m}^{-2}$ and $103.43 \pm 6.82 \mathrm{~W} . \mathrm{m}^{-2}$ at 2:00 p.m. for the Sindhi and Guzerat heifers, respectively. Under these conditions (air temperature was between 29 and $30^{\circ} \mathrm{C}$ ), $84 \%$ of the total latent heat loss in Sindhi and Guzerat heifers was represented by $\mathrm{E}_{\mathrm{c}}$. It can be concluded that Sindhi and Guzerat heifers can maintain homeothermy with minimal thermoregulatory effort under shade conditions in a tropical environment.
\end{abstract}

Key words: Heat tolerance. Physiological parameters. Prediction models. Zebu cattle.

\section{Resumo}

Objetivou-se com este estudo caracterizar o ambiente térmico e respostas fisiológicas de novilhas Sindi e Guzerá em ambiente tropical. Oito novilhas Sindi e oito Guzerá (Bos indicus) foram utilizadas para medições fisiológicas duas vezes ao dia (09:00 e 14:00). Durante o período experimental, os dados ambientais foram coletados em intervalos de duas horas, entre 05:00 e 17:00. O índice de temperatura-

\footnotetext{
${ }^{1}$ Discentes do Curso de Doutorado do Programa de Pós Graduação em Zootecnia, Universidade Federal da Paraíba, UFPB, Areia, PB, Brasil. E-mail: vinicius_fonseca86@hotmail.com; gabrielh18@hotmail.com

2 Prof. Adjunto, Universidade Federal do Amazonas, Capanema, PA, Brasil. E-mail: ebsonzoo@yahoo.com.br

${ }^{3}$ Profs. Adjuntos, Programa de Pós Graduação em Zootecnia, PPGZ/PDIZ/UFPB, Areia, PB, Brasil. E-mail: gonzaga@cca.ufpb. br; edilson@cca.ufpb.br; carla@cca.ufpb.br

${ }^{4}$ Prof. Adjunto, Programa de Pós-Graduação de Construções Rurais e Ambiência, Universidade Federal de Campina Grande, UFCG, Campina Grande, PB, Brasil. E-mail: dermeval@deag.ufcg.edu.br

5 Mestres em Zootecnia pelo Programa de Pós Graduação em Ciência Animal, UFCG, Patos, PB, Brasil. E-mail: jeanfvasco@ hotmail.com; jeorge_vieira@hotmail.com

* Author for correspondence
} 
umidade (ITU) e o de globo negro-umidade (ITGU) foram calculados. Foram aferidas a temperatura de superfície $\left(T_{S}\right)$, frequência respiratória $\left(F_{R}\right)$ e a temperatura retal $\left(T_{R}\right)$, sendo estimados a perda de calor por evaporação cutânea $\left(\mathrm{E}_{\mathrm{C}}\right)$ e pelo trato respiratório $(\mathrm{Er})$. Nos horários mais quentes do dia (01:00 e 15:00), o ITU e ITGU atingiram valores de 80,26 e 81,25, respectivamente. Não houve diferença significativa para a temperatura retal entre as raças, contudo, valores mais elevados foram observados no período da tarde. As estimativas para a transferência de calor latente via evaporação cutânea atingiram $118,71 \pm 12,91 \mathrm{~W} \cdot \mathrm{m}^{-2}$ e 103,43 $\pm 6,82 \mathrm{~W} \cdot \mathrm{m}^{-2}$ no período da tarde (2:00) para as novilhas Sindi e Guzerá, respectivamente. Em condições de temperatura do ar entre 29 e $30^{\circ} \mathrm{C}, 84 \%$ da perda de calor latente total em novilhas Sindi e Guzerá foi representada pela Ec. Pode-se concluir que novilhas Sindi e Guzerá criadas em condições de sombra, numa região tropical, conseguem manter a homeotermia com baixo dispêndio de energia para a termorregulação.

Palavras-chave: Bovinos zebuínos. Modelos de predição. Parâmetros fisiológicos. Tolerância ao calor.

\section{Introduction}

Physiological parameters can be used to evaluate the adaptability of cattle to a specific environment and this has been done in several studies (MULLER; BOTHA, 1993; BROWN-BRANDL et al., 2006; GAUGHAN et al., 2009; MCMANUS et al., 2011; COSTA et al., 2015). Changes in the thermal energy balance such as an increase in the respiratory rate or variations in body temperature above a narrow permissible range are some of the animal's responses to environmental conditions that are outside their thermal comfort zone.

When air temperature is above of the upper critical, evaporative heat loss is greater in order to maintain thermal equilibrium in animals (MAIA et al., 2005a). Cattle heat loss by evaporation occurs mainly at the epidermis and, accounts for approximately $80 \%$ of the total loss under heat stress conditions (MCLEAN, 1963; FINCH, 1985; MAIA et al., 2005a; SILVA et al., 2012).

Some researchers have developed mathematical models that use indirect measures such as respiratory rate and surface temperature to predict latent heat flow in cattle (MAIA et al., 2005b; SILVA; MAIA, 2011; SILVA et al., 2012). These studies showed that heat loss by cutaneous evaporation is determined by surface temperature and, latent heat loss through the respiratory tract is based on the respiratory rate and the relationship between the vapor pressure of inspired and expired air.
Indirect measures to estimate an animal latent heat balance and other physiological indicators of adaptability, are important tools to establish the effect of breed-environment interaction on the thermoregulatory responses of cattle. Furthermore, most studies on Bos indicus in tropical environments have investigated Nellore cattle, and little attention has been given to other breeds, such as Sindhi and Guzerat (NAVARINE et al., 2009; MCMANUS et al., 2011; COSTA, 2013). Therefore, the present study aimed to verify the physiological aspects of acclimatization of Sindhi and Guzerat heifers in confinement not exposed to the sun. We suggest that Sindhi and Guzerat heifers when reared in tropical conditions but not exposed to the sun could maintain homeothermy with minimal thermoregulatory effort.

\section{Materials and Methods}

The study was conducted from June 18 to August 27, 2009 at the Livestock Experimental Station in Alagoinha, PB, Brazil (6 $6^{\circ} 57^{\prime} 00^{\prime}$ ' S, $35^{\circ} 32^{\prime} 42^{\prime}$ ' $\mathrm{W}, 135 \mathrm{~m}$ altitude). Sixteen purebred heifers (Bos indicus), eight Sindhi and eight Guzerat, with a mean age of $21 \pm 4.2$ months were used. The Guzerat heifers had a mean body weight of $268.17 \pm 22 \mathrm{~kg}$, and the Sindhi heifers had a mean body weight of $211.7 \pm 21 \mathrm{~kg}$. The animals were maintained in a housed condition. The experimental diets were formulated to meet the nutritional requirements of growing heifers (NRC, 2001) (Table 1). Feeding 
was divided into two daily servings, one at 7:00 a.m., which offered $40 \%$ of the daily portion, and the other at 3:00 p.m., which offered 60\%. Access to water was not restricted.

The heifers were housed in individual pens that were built with an east-west orientation, measured
$7.5 \mathrm{~m}^{2}$ in area, and were provided with feeders and drinkers. The material used in the roof was fiber cement roof, which has a thermal conductivity (k) of $0.63 \mathrm{Wm}^{-1} \mathrm{~K}$ (MONTEITH; UNSWORTH, 2008). The animals were never exposed to direct short-wave radiation.

Table 1. Ingredients and chemical composition of the experimental diet based on dry matter.

\begin{tabular}{lcc}
\hline \multirow{2}{*}{$\quad$ Ingredients } & & (\%) \\
\cline { 2 - 3 } & Guzerat Diet & Sindhi Diet \\
\hline Pennisetum purpureum & 39.17 & 30.00 \\
Cassava root & 30.00 & 31.31 \\
Cornmeal & 21.76 & 24.70 \\
Soybean meal & 5.87 & 10.90 \\
Urea & 1.65 & 1.58 \\
Mineral salt & 1.55 & 1.51 \\
\hline Chemical composition & & \\
\hline Dry matter & 49.32 & 54.35 \\
Crude protein & 13.51 & 15.55 \\
Ether extract & 2.49 & 2.53 \\
Neutral detergent fiber & 37.73 & 32.66 \\
Neutral detergent fiber cp & & 27.96 \\
Acid detergent fiber & 33.20 & 19.34 \\
Total Carbohydrates & 22.43 & 78.28 \\
Non-fibrous carbohydrates & 79.97 & 37.99 \\
\hline
\end{tabular}

${ }^{1}$ Corrected for ash and protein.

Environmental variables were collected at twohour intervals from 5:00 a.m. to 5:00 p.m. every day during the experimental period. Air temperature $\left(\mathrm{T}_{\mathrm{a}}\right)$, black globe temperature $\left(\mathrm{T}_{\mathrm{g}}\right)$, and relative humidity $\left(R_{H}\right)$ were recorded. $T_{a}, T_{g}$, and $R_{H}$ were measured using a mini portable weather station placed inside the confinement pens $1.2 \mathrm{~m}$ from the ground. The black globe temperature was measured using a thermometer inserted into a conventional blackened hollow sphere (15 $\mathrm{cm}$ diameter) painted with matte black ink. The temperature-humidity index (THI) and the black globe temperaturehumidity index (BGHI) calculations were based on the $\mathrm{T}_{\mathrm{a}}$ and $\mathrm{T}_{\mathrm{g}}$, variables.
The THI was calculated using the equation in Thom (1959):

$$
\mathrm{THI}=\mathrm{T}_{\mathrm{a}}+\left(0.36 \times \mathrm{W}_{\mathrm{BT}}\right)+41.5
$$

where $\mathrm{W}_{\text {Вт }}$ is the wet bulb temperature. The BGHI was calculated using the equation in Buffington et al. (1981):

$$
\mathrm{BGHI}=\mathrm{T}_{\mathrm{g}}+0.36 \mathrm{~T}_{\mathrm{d}}-330.08
$$

where $T_{d}$ is the dew point temperature measured in Kelvin.

Physiological traits were recorded twice a day (9:00 a.m. and 2:00 p.m.). The heifers were moved to a contention trunk in a corral beside the confinement area. Rectal temperature $\left(\mathrm{T}_{\mathrm{r}}\right)$, respiratory rate 
$\left(\mathrm{R}_{\mathrm{r}}\right)$, and surface temperature $\left(\mathrm{T}_{\mathrm{s}}\right)$ were measured. To obtain $\mathrm{T}_{\mathrm{r}}$, a digital clinical thermometer was introduced into the animal's rectum. The $\mathrm{R}_{\mathrm{r}}$ was assessed when the animals were inside their pens, before they were led to the contention trunk, by counting the animals' flank movements for $15 \mathrm{~s}$; this was later multiplied by four to calculate the number of breaths per minute. The $\mathrm{T}_{\mathrm{s}}$ was measured using an infrared thermometer (Horiba, mod. IT - 330), that had an adjusted emissivity of 0.98. It was directed perpendicular to the animals' surface at a distance of $20 \mathrm{~cm}$ from the following regions: the head, the back, the shin, and the udder. The $\mathrm{T}_{\mathrm{s}}$ value was determined according to the equation in Pinheiro et al. (2005):

$$
\mathrm{T}_{\mathrm{s}}=0.1 \cdot \mathrm{T}_{\text {head }}+0.7 \cdot \mathrm{T}_{\text {back }}+0.12 \cdot \mathrm{T}_{\text {shin }}+0.08 \cdot \mathrm{T}_{\text {udder }}
$$

Mathematical models developed by Maia et al. (2005b) and Silva et al. (2012) were used in order to estimate latent heat flux through the respiratory tract:

$$
\mathrm{E}_{\mathrm{r}}=\lambda\left(\Psi_{\mathrm{EXP}}-\Psi_{\mathrm{ATM}}\right) / \mathrm{r}_{\mathrm{VR}} \mathrm{W} \cdot \mathrm{m}^{-2}
$$

where $\mathrm{E}_{\mathrm{r}}$ is the heat flux through the respiratory

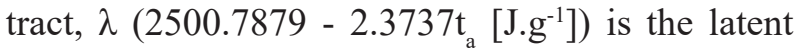
heat of water vaporization, $\Psi_{\text {EXP }}$ is the absolute humidity $\left(\mathrm{g} \cdot \mathrm{m}^{-3}\right)$ of the expired air, $\Psi_{\text {АTM }}$ is the atmospheric absolute humidity, and $\mathrm{r}_{\mathrm{vR}}$ is the water vapor resistance to heat loss through the respiratory tract. In order to estimate the absolute atmospheric humidity we used the following equation:

$$
\Psi_{\text {ATM }}=2166.869 \mathrm{P}_{\mathrm{V}} /\left(\mathrm{T}_{\mathrm{a}}+273.15\right) \mathrm{g} \cdot \mathrm{m}^{-3}
$$

where $\mathrm{P}_{\mathrm{V}}$ is the vapor pressure of air at a given air temperature $\left(\mathrm{T}_{\mathrm{a}}\right)$, calculated using the equation:

$$
\mathrm{P}^{*}{ }_{\mathrm{V}}\left\{\mathrm{T}_{\mathrm{a}}\right\}=0.61078 \times 10^{7.5 \mathrm{Ta} /(\mathrm{Ta}+237.5)} \mathrm{K}_{\mathrm{pa}}
$$

The absolute humidity of the expired air $\left(\Psi_{\text {EXP }}\right)$ was calculated according to the following equations developed by Silva et al. (2012) and Maia et al. (2005b):

$$
\begin{aligned}
& \Psi_{\mathrm{EXP}}=2166.869 \mathrm{P}_{\mathrm{VEXP}} /\left(\mathrm{T}_{\mathrm{EXP}}+273.15\right) \mathrm{g} \cdot \mathrm{m}^{-3}, \\
& \mathrm{~T}_{\mathrm{EXP}}=9.47+1.18 \mathrm{~T}_{\mathrm{a}}-0.01278 \mathrm{~T}_{\mathrm{a}}^{20} \mathrm{C},
\end{aligned}
$$

$\mathrm{P}_{\mathrm{V}}^{*}\left\{\mathrm{~T}_{\mathrm{EXP}}\right\}=0.61078 \times 10^{7.5 \mathrm{~T}} \underset{\mathrm{EXP}}{/(\mathrm{T}}{ }_{\text {EXP }}{ }^{+237.5)} \mathrm{K}_{\mathrm{PA}}$

where $\mathrm{P}_{\mathrm{V}(\mathrm{EXP})}$ is the vapour pressure of the expired air and $\mathrm{T}_{\mathrm{EXP}}$ is expired air temperature. Finally, the water vapor resistance to heat loss through the respiratory tract $\left(\mathrm{r}_{\mathrm{VR}}\right)$ was given by the following function:

$$
r_{V R}=2583.921-48.445 R_{r}+0.3414 R_{r}^{2}-2.037
$$
$\mathrm{T}_{\mathrm{a}} \mathrm{S} \cdot \mathrm{m}^{-1}$

In order to estimate the heat loss by cutaneous evaporation, the exponential model developed by Silva and Maia (2011) as a function of the animal's surface temperature $\left(\mathrm{T}_{\mathrm{S}}\right)$ was used:

$$
\mathrm{E}_{\mathrm{c}}=31.5+3.67 \mathrm{e}^{(\mathrm{Ts}-27.9) / 2.1915} \mathrm{~W} \cdot \mathrm{m}^{-2}
$$

Data were analyzed by the least square methods (HARVEY, 1960). The General Linear Model (GLM) procedure was used to test the effects of breed (Sindhi or Guzerat) and time of the day (9:00 a.m. or 2:00 p.m.) on the physiological traits. The following mathematical model was used in the analysis of variance for $T_{s}, R_{r}, T_{r}, E_{c}$, and $E_{r}$ :

$$
\mathrm{y}_{\mathrm{ijk}}=\mu+\mathrm{B}_{\mathrm{i}}+\mathrm{T}_{\mathrm{j}}+\mathrm{I}_{\mathrm{ij}}+\mathrm{e}_{\mathrm{ijk}}
$$

where $\mathrm{y}_{\mathrm{ijk}}=$ the $\mathrm{k}^{\text {th }}$ observation on the $\mathrm{j}^{\text {th }}$ time of day of the $\mathrm{i}^{\text {th }}$ breed; $\mathrm{B}_{\mathrm{i}}=$ the fixed effect of the $i^{\text {th }}$ breed $(I=$ Sindhi or Guzerat $) ; T_{j}=$ the effect of the $\mathrm{j}^{\text {th }}$ time of the day $(\mathrm{j}=9: 00$ a.m. or 2:00 p.m.); $I_{i j}$ represents the interaction effects between the $i^{\text {th }}$ breed and the $\mathrm{j}^{\text {th }}$ time of the day; and $\mu$ and $\varepsilon_{\mathrm{ijk}}=$ the overall mean and the error term, respectively. The statistical package used for all analyses was SAS version 9.3 (SAS Inst. Inc., Cary, NC, USA).

\section{Results and Discussion}

Air temperature varied during the day $(\mathrm{P}<$ $0.05)$, and ranged from $23.30 \pm 1.5$ to $29.80 \pm 2.1$ between 5:00 a.m. and 5:00 p.m. The temperatures were highest between 11:00 a.m. and 3:00 p.m. (Figure 1). According to Brown-Brandl et al. (2006), the thermoneutral zone (TNZ) generally ranges between 10 and $30^{\circ} \mathrm{C}$ for most adult cattle 
breeds. Gaughan et al. (2009) reported that the heat tolerant Bos indicus must have an upper end for TNZ that is greater than that for typical Bos taurus cattle. Baêta and Souza (2010) reported $34^{\circ} \mathrm{C}$ as being the upper end of the thermoneutral zone for Zebu cattle.

Figure 1. Environmental data (mean $\pm \mathrm{SEM}$ ) measured during the experimental period at each two hours.

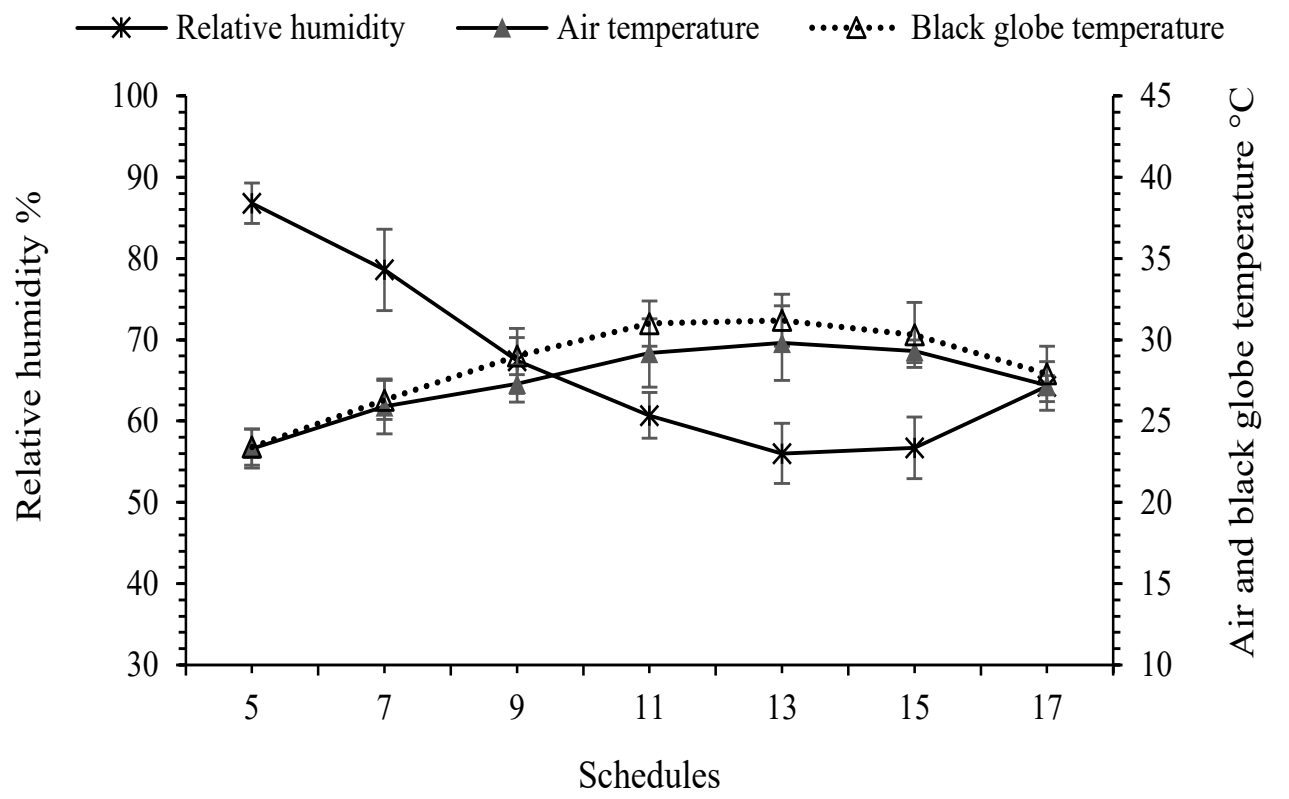

In the TNZ, an animal can maintain homeostasis through normal physiological and metabolic processes, which require minimal expenditure of energy (BERNABUCCI et al., 2010). In our study, the air temperature was maintained within a suitable range for both breeds. In regions with low latitudes, such as the tropics, there is little variation in the average annual temperature, and $\mathrm{T}_{\mathrm{a}}$ does not seem to cause significant changes in the physiology and metabolism of adult Zebu cattle.

High values for $R_{h}$ were observed early in the day when the air temperature was lowest. The opposite was observed when the air temperature was highest (Figure 1). The $\mathrm{R}_{\mathrm{h}}$ daily variation range was $56 \pm 2.20$ to $86.8 \pm 2.16 \%$. The variation in $\mathrm{T}_{g}$ (range: $23.30 \pm 1.5$ to $31.20 \pm 0.6$ ) was similar to $\mathrm{T}_{\mathrm{a}}$ (Figure 1). In shade conditions, $\mathrm{T}_{\mathrm{g}}$ is not affected by short-wave radiation and its values are therefore close to the air temperature.
Even in shade conditions, indirect long-wave radiation emitted from the roof can be significant for housed cattle, and the use of materials with a high thermal capacity becomes relevant. Roof materials should therefore have appropriate thermophysical properties. In our study, cement fiber roof was used as a roofing material. This material has an emissivity $(\varepsilon)$ of 0.97 and a thermal conductivity $(k)$ of 0.67 W.m ${ }^{-2}$ (CHAPMAN, 1987; MONTEITH; UNSWORTH, 2008).

Values of between 72.23 and 80.26 were observed during the experimental period for the temperature-humidity index (THI) and 72.00 and 81.5 for the BGHI (Figure 2). Previous studies with dairy cattle, mainly using the THI and BGHI indices, have reported consistent results with regard to the classification of the ideal environment for raising cattle in temperate climates (BUFFINGTON et al., 1981). According to the National Weather 
Service (USA) classification, the limits of the THI and BGHI for dairy cattle are as follows: up to 74 represents a comfortable situation, 74-78 triggers an alert state, 79-84 represents a dangerous situation, and over 84 is an emergency.

Figure 2. Temperature-humidity index (THI), black globe temperature-humidity index (BGHI); (mean \pm SEM) calculated during the experimental period.

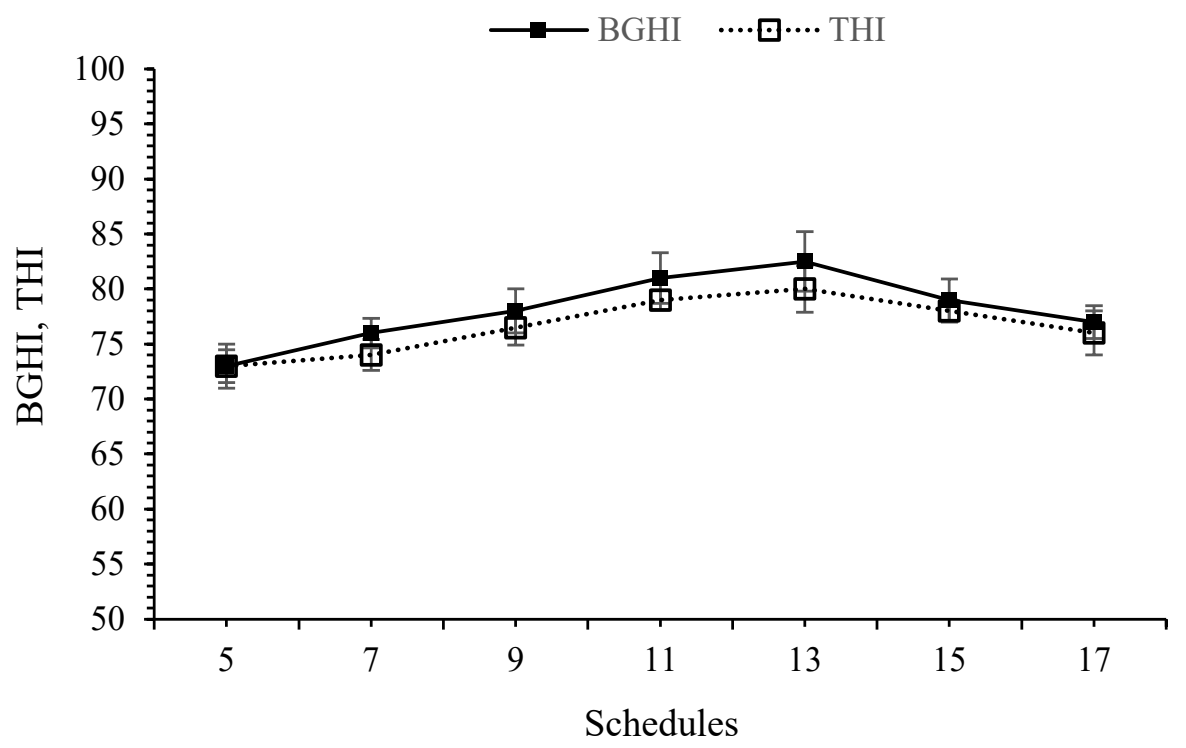

Despite its obvious limitations, the THI has been frequently used in the classification of environments for cattle raised in tropical regions, using the argument that it is correlated with the productive performance of the animal; however, such arguments are valid only when they are related to temperate regions, where the index was developed (BOHMANOVA et al., 2007; SILVA et al., 2007; ZIMBELMAN et al., 2009; SILVA et al., 2014). In the case of genotypes that are more adapted to tropical conditions, the values set for the climatic environmental classification of Holstein cattle less adapted to these conditions may be overestimated for other genotypes, such as Sindhi and Guzerat cattle.

There was no significant difference $(\mathrm{P}>0.05)$ in surface temperature between Sindhi and Guzerat cattle (Table 2; Table 3). However, for both breeds, the surface temperature was higher at 2:00 p.m. than in the morning (9:00 a.m.). The amount of energy from the environment that is absorbed at the animal's surface, together with the heat that is transferred from the inner core to the periphery by circulatory convection, which determines the animal's surface temperature. Hair color, epidermis and hair conformation influence surface temperature (SILVA et al., 2003; BROWN-BRANDL et al., 2006). Cattle with shorter and wider hair, and a light-colored coat are more adapted to hot environments than those with long-haired, darker coats (GAUGHAN et al., 2009; JIAN et al., 2013). These characteristics are common to both breeds that we studied, except for coat color (Sindhi cattle have red hair).

With respect to hair coat color, we expected a higher surface temperature on Sindhi cattle, which have red hair, than on Guzerat cattle, which have white-gray hair, due to the greater heat absorbance ( $\alpha$ ) of red hair $\alpha=0.777$, compared to 0.54 for white hair (SILVA; MAIA, 2012). Silva et al. (2003) reported that Nellore cattle, which have a mixture of 
white and dark hair, similar to Guzerat, had a higher reflectance $(\rho)$ than cattle with white hair, and that gray coats reflect better than red coats at the 300 $600 \mathrm{~nm}$ wave lengths. This spectrum comprises of short-wave radiation. However, we maintained the animals in shade conditions and so did not observe any differences in surface temperature between the breeds.

Table 2. Means square of surface temperature (St), respiratory rate $(\mathrm{Rr})$, heat loss by cutaneous evaporation $(\mathrm{Ec})$ and heat loss by respiratory evaporation (Er) of Sindhi and Guzerat heifers.

\begin{tabular}{ccccccc}
\hline Source & d.f & $\mathrm{S}_{\mathrm{t}}$ & $\mathrm{R}_{\mathrm{r}}$ & $\mathrm{R}_{\mathrm{t}}$ & $\mathrm{E}_{\mathrm{c}}$ & $\mathrm{E}_{\mathrm{r}}$ \\
\hline Breed & 1 & $1.3021 \mathrm{~ns}$ & $689.4525^{* *}$ & $1.7981 \mathrm{~ns}$ & $1,854.9799 \mathrm{~ns}$ & $1.5689 \mathrm{~ns}$ \\
Time of the day & 1 & $137.2647^{* *}$ & $31.5584 \mathrm{~ns}$ & $4.8870^{* *}$ & $63,063.9033^{* *}$ & $1.3241 \mathrm{~ns}$ \\
Residual & 80 & 12.5144 & 46.2063 & 1.6800 & $2,999.6522$ & 1.6647 \\
\hline
\end{tabular}

ns $=$ statistically non-significant; $* * \mathrm{P}<0.01$.

Table 3. Physiological traits (mean \pm SEM) of Sindhi and Guzerat heifers.

\begin{tabular}{|c|c|c|c|c|c|}
\hline Response variable & \multicolumn{2}{|c|}{ Time of the day } & \multicolumn{3}{|c|}{$\mathrm{P}$-value } \\
\hline Surface temperature, ${ }^{\circ} \mathrm{C}$ & $\begin{array}{c}\text { 9:00 a.m. } \\
(n=92)\end{array}$ & $\begin{array}{r}2: 00 \text { p.m. } \\
(n=88)\end{array}$ & Breed & $\begin{array}{c}\text { Time of the } \\
\text { day }\end{array}$ & $\begin{array}{c}\text { Breed vs time } \\
\text { of the day }\end{array}$ \\
\hline Sindhi & $31.63 \pm 0.2 b$ & $34.15 \pm 0.25 \mathrm{a}$ & \multirow{2}{*}{0.3600} & \multirow{2}{*}{0.0001} & \multirow{2}{*}{0.8817} \\
\hline Guzerat & $31.85 \pm 0.2 b$ & $34.45 \pm 0.30 \mathrm{a}$ & & & \\
\hline \multicolumn{6}{|l|}{ Respiratory rate, $\mathrm{min}^{-1}$} \\
\hline Sindhi & $33.63 \pm 1.2 \mathrm{~B}$ & $34.40 \pm 1.54 \mathrm{~B}$ & \multirow{2}{*}{0.0002} & \multirow{2}{*}{0.4110} & \multirow{2}{*}{0.7557} \\
\hline Guzerat & $38.90 \pm 1.3 \mathrm{~A}$ & $40.60 \pm 1.72 \mathrm{~A}$ & & & \\
\hline \multicolumn{6}{|l|}{ Rectal temperature, ${ }^{\circ} \mathrm{C}$} \\
\hline Sindhi & $38.50 \pm 0.2 \mathrm{a}$ & $38.90 \pm 0.05 b$ & \multirow{2}{*}{0.0821} & \multirow{2}{*}{0.0042} & \multirow{2}{*}{0.9902} \\
\hline Guzerat & $38.80 \pm 0.2 \mathrm{a}$ & $39.28 \pm 0.04 b$ & & & \\
\hline
\end{tabular}

Means with different letter (lower case in the same line and capital letter in the same column) differ statistically by $\mathrm{f}$ test $(\mathrm{P}<0.05)$.

Furtado et al. (2012) obtained similar results in a study on Sindhi and Guzerat calves in confinement. They also did not observe any surface temperature differences between breeds. In study with Nellore cattle, Costa (2013) reported an increase in surface temperature when these animals were transferred of the shade condition to the exposition to the sun. According to Martello et al. (2004), values between $31.6^{\circ} \mathrm{C}$ and $34.7^{\circ} \mathrm{C}$ are considered normal for cattle bred in regions with hot climates. Overall, our results showed that even during the hottest time of the day (2:00 p.m.) the surface temperature was higher than the air temperature, although the difference was smaller, which favored the loss of heat by sensible processes. As air temperatures approach surface temperatures, evaporation becomes the major route for heat exchange with the environment.

Predictions for heat transfer by cutaneous evaporation were similar $(\mathrm{P}>0.05)$ for both breeds. When the time-of-day effect was considered, we observed that cutaneous evaporation increased in the afternoon (2:00 p.m.), and at this point, ranges of $118.71 \pm 12.91$ and $103 \pm 6.82$ were observed in Guzerat and Sindhi heifers, respectively (Figure $3)$. Under tropical condition, at a temperature of $30^{\circ} \mathrm{C}$, Maia et al. (2005a) recorded a range of 250 to $300 \mathrm{~W} \cdot \mathrm{m}^{2}$ for heat loss by cutaneous evaporation 
in Holstein cows. These results suggested that in a similar environment, the energetic costs of thermoregulation are higher for Holstein cows than for Guzerat and Sindhi heifers.

The respiratory rate was higher in Guzerat cattle ( $\mathrm{P}<0.05$; Table 3$)$. However, there was no significant effect of time of the day, and during the warmest period (2:00 p.m.) the animals did not increase their respiratory rates $(\mathrm{P}>0.05)$. According to Hahn et al. (1997), 60 respiratory movements do not represent a stressful situation for cattle bred in tropical environments. Pereira et al. (2008) reported that cattle under heat stress that are suited to hot climates increase their respiratory frequency to 80 movements per minute at $34^{\circ} \mathrm{C}$. The increased respiratory rate in Guzerat heifers can be attributed to their temperament, since these animals were more reactive than Sindhi at the time of data collection. Gaughan et al. (2000) stated that respiratory frequency is a good indicator of an animal's thermal condition; however, other factors need to be taken into account when interpreting the results.

Figure 3. Respiratory heat loss and heat loss by cutaneous evaporation (mean \pm SEM) estimated in Sindhi and Guzerat heifers.

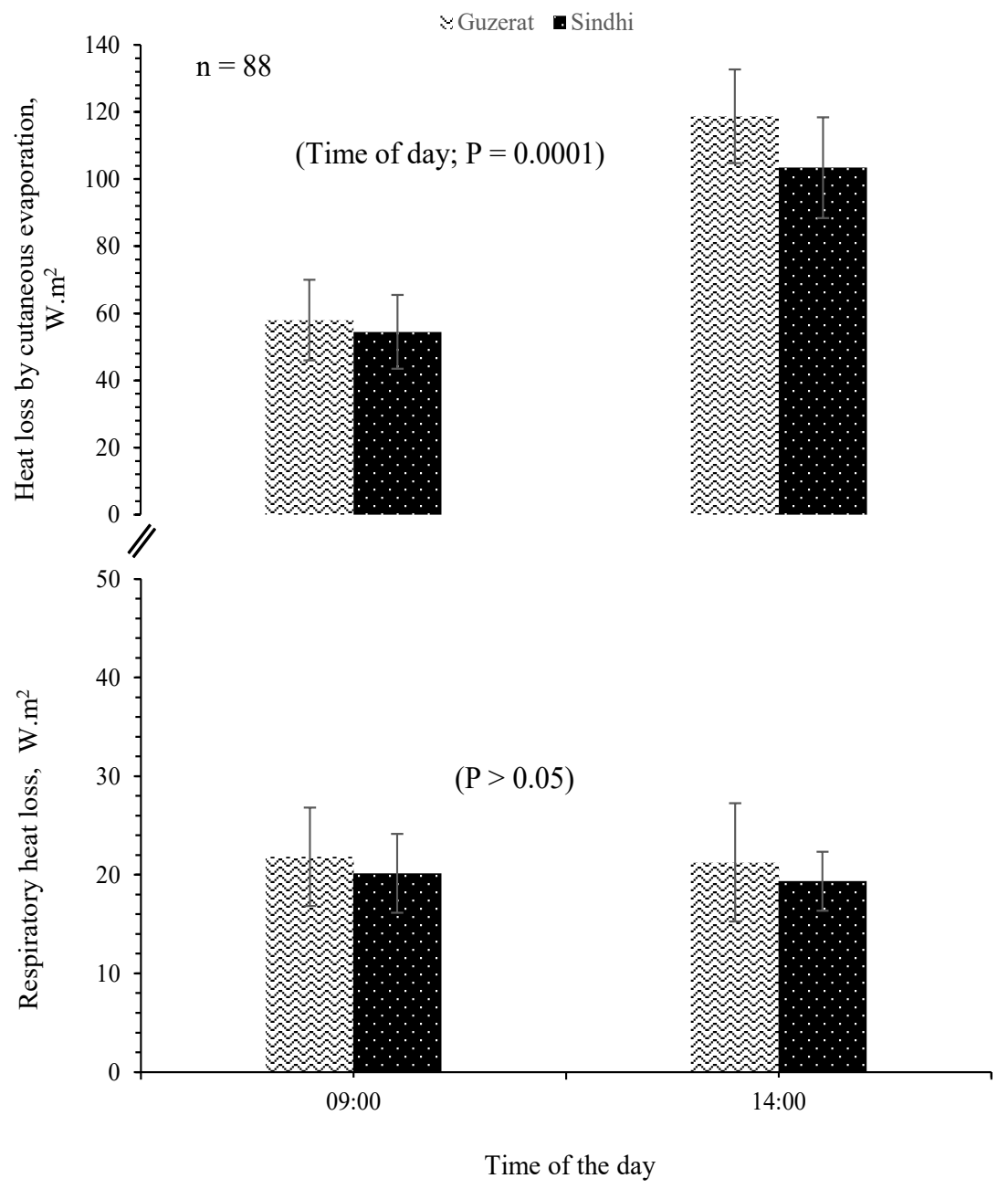


Regarding latent heat transfer, the amount of energy lost through the respiratory process did not differ between breeds $(\mathrm{P}>0.05)$, or between time of the day (Figure 3). The efficiency of this process depends on the vapor pressure in the atmosphere. The air volume that is expired by an animal (tidal volume) is negatively correlated with the number of breaths per minute, i.e., as the respiratory frequency increases, the amount of vapor contained in the expired air decreases (STEVENS, 1981; MAIA et al., 2005b). As consequence, the amount of heat transfer by respiration is reduced; increase in respiratory activity cause an additional production of internal heat, reducing the efficiency of this heat transfer mechanism. In addition, high respiratory rate can lead to serious physiological damage in animals, such as decreased partial pressure of $\mathrm{CO}_{2}$ in the arterial blood (MAIA et al., 2005b).

According our results, when the air temperature increased, respiratory rate and latent heat transfer by the respiratory tract remained constant. At 9:00 $\left(\mathrm{T}_{\mathrm{a}}\right.$ of $27.30 \pm 0.90)$ the heat of respiratory tract accounted $26 \%$ of the total latent heat loss and at 2:00 p.m. $\left(\mathrm{T}_{\mathrm{a}}\right.$ of $29.80 \pm 1.20$ ) this proportion decreased for 16 $\%$ of the total latent heat loss. In a situation of heat stress, evaporative heat loss via respiration rate can be greater for European breeds and this occurrence probably reflects the grater engagement of heat loss mechanism for the less adapted breed (HENSEN, 2004).

There was no difference in rectal temperature between breeds $(\mathrm{P}>0.05)$, and the animals' homeothermy was maintained in both assessment periods during the day (morning and afternoon), although there was a increase $(\mathrm{P}<0.05)$ in the afternoon (Table 3). However, the observed values were within the normal range for the species, which according to Baêta and Souza (2010) is $38.5^{\circ} \mathrm{C}$ to $39.5^{\circ} \mathrm{C}$. It was reported that Bos indicus cattle has a low metabolism when compared with European cattle. Animals with low metabolism has a greater capacity to heat storage. In addition, heavier individuals store more energy and require proportionally lower heat production rate (SILVA, 2000). Our results showed a slight tendency in higher rectal temperature for Guzerat heifers.

In a study of a Sindhi heifers herd in the Brazilian semiarid region, Souza et al. (2007) reported a significant increase in rectal temperature in the afternoon; however, this increase did not represent a state of hyperthermia. Comparing the degrees of adaptation of five different cattle breeds under heat stress conditions, such an air temperature of $34^{\circ} \mathrm{C}$ in climate chambers, Pereira et al. (2008) reported hyperthermia (body core temperature of $41.2^{\circ} \mathrm{C}$ ) in Holstein and Limousin breeds.

Even under environmental conditions in which animals can maintain homeothermy, minor variations in body temperature are observed and, the magnitude of these changes can correspond to the thermoregulatory adjustments that animals expend to maintain thermal equilibrium. However, an adaptive mechanism in species bred in arid regions is thermal storage. In this process, the heat received from the environment is stored, leading to a significant increase in the animal's body temperature (SILVA, 1999; BROSH et al., 1998). This excess heat is eliminated at night by sensible mechanisms, due to the high thermal gradient that exists at this time. In terms of energetic costs, this mechanism present more economy for the animal, because the excessive physiological changes to maintain homeotermy require high use of net energy. No studies reported clearly this mechanism at some Bos indicus breeds; however, their process of genetic adaptation suggests that these animals has a thermoregulatory mechanism more efficiently than Bos taurus.

According to the physiological traits measured in this study, Sindhi and Guzerat heifers maintained homeothermy with minimal thermoregulatory effort. Thus, the use of shade in a confinement or grazing system in tropical environments, even for breeds more adapted as Zebu cattle, can represent a less energy expenditure for the thermoregulation 
and consequently better performance for these animals.

\section{Conclusions}

The fiber cement roof can be used in shade structures for cattle bred in tropical conditions. Sindhi and Guzerat heifers can maintain homeothermy with minimal thermoregulatory effort under shade conditions in a tropical environment.

\section{References}

BAÊTA, F. C.; SOUZA, C. F. Ambiência e edificações rurais: conforto animal. 2. ed. Viçosa, MG: Universidade Federal de Viçosa, 2010. 269 p.

BERNABUCCI, U.; LACETERA, N.; BAUMGARD, L. H.; RHOADS, R. P. Metabolic and hormonal acclimation to heat stress in domesticated ruminants. Animal, Cambridge, v. 7, n. 1, p. 1167-1183, 2010.

BOHMANOVA, J.; MISZTAL, I.; COLE, J. B. Temperature humidity indices as indicators of milk production losses due to heat stress. Journal of Dairy Science, Champaign, v. 90, n. 4, p. 1947-1956, 2007.

BROSH, A.; AHARONI, Y.; DEGEN, A. A. Effects of solar radiation, dietary energy, and time of feeding on thermoregulatory responses and energy balance in cattle in a hot environment. Journal of Animal Science, Champaign, v. 76, n. 2, p. 2671-2677, 1998.

BROWN-BRANDL, T. M.; EIGENBERG, R. A.; NIENABER, J. A. Heat stress risk factors of feedlot heifers. Livestock Science, Foulum, v. 105, n. 3, p. 57-68, 2006.

BUFFINGTON, D. E.; COLLAZO-AROCHO, A.; CANTON, G. H.; PITT, D. Black globe-humidity índex (BGHI) as a comfort equation for dairy cows. Transactions of the Asabe, Minneapolis, v. 24, n. 4, p. 711-714, 1981

CHAPMAN, A. J. Fundamentals of heat transfer. New York: Macmillan, 1987. 660 p.

COSTA, A. N. L.; FEITOSA, J. V.; MONTEZUMA JÚNIOR, P. A.; SOUZA, P. T.; ARAUJO, A. A. Hormonal profiles, physiological parameters, and productive and reproductive performances of Girolando cows in the state of Ceará-Brazil. International Journal of Biometeorology, Milwaukee, v. 59, n. 1, p. 231-236, 2015.
COSTA, C. C. M. Efeito da radiação solar e temperatura na emissão de metano associado à produção e perda de calor em bovinos. 2013. Dissertação (Mestrado em Zootecnia) - Faculdade de Ciências Agrárias e Veterinárias, Universidade Estadual Paulista Júlio de Mesquita Filho, Jaboticabal.

FINCH, V. A. Comparison of non-evaporative heat transfer in different cattle breeds. Australian Journal of Agriculture Research, Clayton, v. 36, n. 4, p. 497-508, 1985.

FURTADO, D. A.; PEIXOTO, A. P.; REGIS, J. E. F.; NASCIMENTO, J. W. B.; ARAUJO, T. G. P.; LISBOA, A. C. C. Thermoregulation and performance of Sindhi and Guzerat young bulls in Agreste region of Paraiba state. Brazilian Journal of Agricultural and Environmental Engineering, Campina Grande, v. 16, n. 2, p. 1022-1028, 2012.

GAUGHAN, J. B.; HOLT, S. M.; HAHN, G. L.; MADER, T. L.; EIGENBERG, R. Respiration rate - is it a good measure of heat stress in cattle? Asian-Australian Journal of Animal Science, Seoul, v. 13, n. 3, p. 329-332, 2000.

GAUGHAN, J. B.; MADER, T. L.; HOLT, S. M.; SULLIVAN, M. L.; HAHN, G. L. Assessing the heat tolerance of 17 beef cattle genotypes. International Journal of Biometeorology, Milwaukee, v. 39, n. 3, p. 200-209, 2009.

HAHN, G. L.; PARKHURST, A. M.; GAUGHAN, J. B. Cattle respiration rate as function of ambient temperature. In: ASAE, 1997, Minneapolis. Proceedings... Minneapoli: [s.n], 1997. p. 1-21.

HARVEY, W. R. Least-Squares analysis of data with unequal subclass numbers. Beltsville: [s.n], 1960. 28 p.

HENSEN, P. J. Physiological and cellular adaptations of zebu cattle to thermal stress. Animal Reproduction Science, Manchester, v. 83, n. 1, p. 349-360, 2004.

JIAN, W.; DUANGJINDA, M.; VAJRABUKKA, C.; KATAWATIN, S. Differences of skin morphology in Bos indicus, Bos taurus, and their crossbreds. International Journal of Biometeorology, Milwaukee, v. 60, n. 5, p. 2832, 2013.

MAIA, A. S. C.; SILVA, R. G.; LOUREIRO, C. M. B. Respiratory heat loss of Holstein cows in a tropical environment. International Journal of Biometeorology, Milwaukee, v. 49, n. 2, p. 332-336, 2005 b.

MAIA, A. S. C.; SILVA, R. G.; LOUREIRO, C. M. B. Sensible and latent heat loss from the body surface of Holstein cows in a tropical environment. International Journal of Biometeorology, Milwaukee, v. 50, n. 3, p. 1722, 2005a. 
MARTELLO, L. S.; SAVASTANO, J. R.; SILVA, S. L. Respostas fisiológicas e produtivas de vacas holandesas em lactação submetidas a diferentes ambientes. Brazilian Journal of Animal Science, Viçosa, v. 33, n. 4, p. 181191, 2004.

MCLEAN, J. A. Measurement of cutaneous moisture vaporization from cattle by ventilated capsules. Journal of Physiology, Paris, v. 24, n. 2, p. 417-426, 1963.

MCMANUS, C.; CASTANHEIRA, M.; PAIVA, S. R.; LOUVANDINI, H.; FIORAVANTI, M. C. S.; PALUDO, G. R.; BIACHINI, E. Use of multivariate analyses for determining heat tolerance in Brazilian cattle. Tropical Animal Health and Production, Edinburgh, v. 43, n. 1, p. 623-630, 2011.

MONTEITH, J. L.; UNSWORTH, M. H. Principles of environmental physics. $3^{\text {th }}$ ed. New York: Academic, 2008. $440 \mathrm{p}$.

MULLER, C. J. C.; BOTHA, J. A. Effect of summer climatic conditions on different heat tolerance factors in primiparous Friesian and Jersey cows. South African Journal of Animal Science, Hatfield, v. 23, n. 4, p. 98103, 1993.

NATIONAL RESEARCH COUNCIL - NRC. Nutrient requirements of dairy cattle. $7^{\text {th }}$ ed. Washington: National Academies Press, 2001. 408 p.

NAVARINE, F. C.; KLOSOWSKI, E. S.; CAMPOS, A. T.; TEIXEIRA, R. A.; ALMEIDA, C. P. Conforto térmico de bovinos da raça nelore a pasto sob diferentes condições de sombreamento e a pleno sol. Engenharia Agrícola, Jaboticabal, v. 4, n. 2, p. 508-517, 2009.

PEREIRA, A. M. F.; BACCARI JÚNIOR, F.; TITTO, E. A. L.; ALMEIDA, J. A. Effect of thermal stress on physiological parameters, feed intake and plasma thyroid hormones concentration in Alentejana, Mertolenga, Frisian and Limousine cattle breeds. International Journal of Biometeorology, Milwaukee, v. 52, n. 3, p. 199-208, 2008.

PINHEIRO, M. G.; NOGUEIRA, J. R.; LIMA, M. L. P.; LEME, P. R.; MACARI, M.; NÄAS, I. A.; LALONI, L. A.; TITTO, E. A. L.; PEREIRA, A. F. Holding pen environment effects on skin temperature, rectal temperature and milk production in Jersey cows. Revista Portuguesa de Zootecnia, Vila Real, v. 12, n. 1, p. 37-43, 2005.

SILVA, R. G. Estimativa do balanço térmico por radiação em vacas holandesas expostas ao sol e à sombra em ambiente tropical. Brazilian Journal of Animal Science, Viçosa, v. 28, n. 2, p. 1403-1408, 1999.
SILVA, R. G. Um modelo para a determinação do equilíbrio térmico de bovinos em ambientes tropicais. Brazilian Journal of Animal Science, Viçosa, v. 29, n. 3, p. 1244-1252, 2000.

SILVA, R. G.; FAÇANHA MORAIS, D. E.; GUILHERMINO, M. M. Evaluation of thermal stress indexes for dairy cows in tropical regions. Brazilian Journal of Animal Science, Viçosa, v. 36, n. 3, p. 11921198, 2007.

SILVA, R. G.; LASCALA JÚNIOR, N.;TONHATI, H. Radiative properties of the body surface of cattle and other animals. Transactions of the Asabe, Minneapolis, v. 46, n. 2, p. 913-918, 2003.

SILVA, R. G.; MAIA, A. S. C. Evaporative cooling and cutaneous surface temperature of Holstein cows in tropical conditions. Brazilian Journal of Animal Science, Viçosa, v. 40, n. 4, p. 1143-1147, 2011.

SILVA, R. G.; MAIA, A. S. C. Principles of animal biometeorology. New Zealand: Springer, 2013. 261 p.

SILVA, R. G.; MAIA, A. S. C.; COSTA, L. L. M. Index of thermal stress for cows (ITSC) under high solar radiation in tropical environments. International Journal of Biometeorology, Milwaukee, v. 59, n. 2, p. 554-559, 2014.

SILVA, R. G.; MAIA, A. S. C.; COSTA, L. L. M.; QUEIROZ, J. A. F. Latent heat loss of dairy cows in an equatorial semi-arid environment. International Journal of Biometeorology, Milwaukee, v. 56, n. 5, p. 927-932, 2012.

SOUZA, B. B.; SILVA, R. M. N.; MARINHO, M. L.; SILVA, G. A.; SILVA, E. M. N.; SOUZA, A. P. Parâmetros fisiológicos e índice de tolerância ao calor de bovinos da raça Sindi no semiárido paraibano. Ciência e Agrotecnologia, Lavras, v. 31, n. 1, p. 883-888, 2007.

STEVENS, D. G. A. model of respiratory vapor loss in Holstein dairy cattle. Transactions of the Asabe, Minneapolis, v. 24, n. 4, p. 151-158, 1981.

THOM, E. C. The discomfort index. Weatherwise, New York, v. 12, n. 2, p. 57-59, 1959.

ZIMBELMAN, R. B.; RHOADS, R. P.; RHOADS, M. L.; DUFF, G. C.; BAUMGARD, L. H.; COLLIER, R. J. A re-evaluation of the impact of temperature humidity index (THI) and black globe humidity index (BGHI) on milk production in high producing dairy cows. In: Southwest Nutrition Conference, 2009, New York. Proceedings... New York: [s.n], 2009. p. 158-169. 
